\title{
Critical Parameters for the Development of Web-Based Knowledge System for Low Volume Rural Roads in Sarawak
}

\author{
Ron Aldrino Chan @ Ron Buking ${ }^{1,2(\bowtie)}$, Muhamad Nazri Borhan ${ }^{2,3}$, \\ Riza Atiq Abdullah O. K. Rahmat ${ }^{2,3}$, and Wan Hashim Wan Ibrahim ${ }^{1}$ \\ ${ }^{1}$ Faculty of Engineering, Department of Civil Engineering, \\ Universiti Malaysia Sarawak (UNIMAS), \\ 94300 Kota Samarahan, Sarawak, Malaysia \\ acron@unimas.my, ronaldrino@gmail.com \\ ${ }^{2}$ Smart and Sustainable Township Research Centre (SUTRA), \\ Universiti Kebangsaan Malaysia (UKM), 43600 Bangi, Selangor, Malaysia \\ ${ }^{3}$ Programme of Civil Engineering, Universiti Kebangsaan Malaysia (UKM), \\ 43600 Bangi, Selangor, Malaysia
}

\begin{abstract}
Low Volume Rural Roads serve as one of the key infrastructure projects for integrated rural development in Sarawak. This road is important to help promote development, improve the flow of goods and services and ensure good public health and education, as well as land and resource management support. The aim of this study is to identify the critical parameters for the development of a knowledge-based system for the design of Low Volume Rural Roads (LVRRs) in Sarawak. A total of eleven experts with more than 10 years of experience have been selected, particularly in the areas of low-volume road design, construction and planning. The questionnaire and feedback form were used to request knowledge from domain experts. According to the survey, experts agreed that all parameters, namely traffic loading, soil condition, type of terrain, geometric features and drainage, are important for the design of lowvolume rural roads.
\end{abstract}

Keywords: Pavement $\cdot$ Low volume roads $\cdot$ Expert system

\section{Introduction}

Low volume roads serve as one of the key infrastructure work, placed for integrated rural development which has become a matter of growing urgency for consideration of social justice, national integration and economic uplift of rural area [3, 4]. Study by Agarwal et al. [1, 2], state that the huge network of rural road that was created in India has resulted in increased in social and economic benefits in rural areas. Also, low volume road provide farm to market access roads, roads connecting communities, and road for logging and mining are also significant parts of any transportation system around the world especially those in the developing countries such as in Malaysia. To help promote development, to improve the flow of goods and services, for a good public health and education, as well as to aid in land and resources management, the 
Dear Prof/ AP/ Dr/ Sir and Madam,

Warm greetings from Department of Civil \& Environmental Engineering, Universiti Teknologi PETRONAS (UTP), Malaysia

First, on behalf of the organizing committee, we would like to thank you for the support in submitting papers to our conference. Also, we would like to congratulate you also on the paper acceptances.

As promised earlier that all accepted papers will be published to the SCOPUS indexed Lecture Notes in Civil Engineering (LNCE) by Springer, in this year 2020 itself. With that, we would like to update that based on the communication with Springer, this conference publication will be tentatively available by $28^{\text {th }}$ Dec 2020 .

We thank you for your patience and apologise for any inconvenience caused during this time of great uncertainty. We are confident that with all of your unwavering support, ESTCON and ICCOEE will be better, bigger and bolder! For more info or to contact us, please email to iccoee2020@utp.edu.my or visit to our website http://estcon.utp.edu.my/iccoee.

Conference Chair,

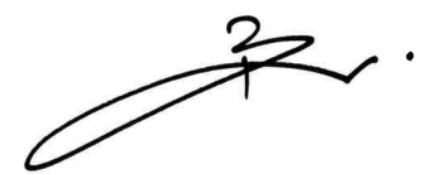

Assoc Prof Ir Dr Bashar S. Mohammed 


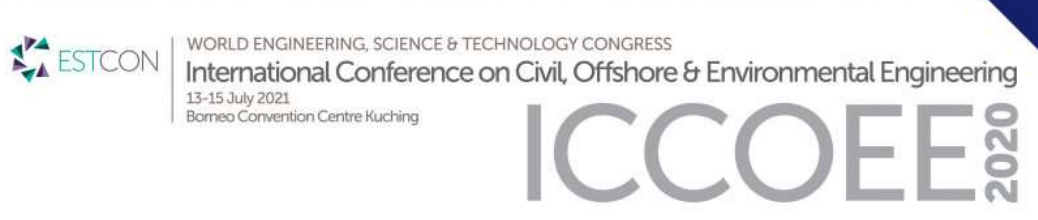

List of accepted papers from UNIMAS

\begin{tabular}{|l|l|}
\hline Corresponding Author & Paper ID \\
\hline Norazlina Bateni & 1570628922 \\
\hline Idawati Ismail & 1570635673 \\
\hline Yee Yong Lee & 1570635866 \\
\hline Sim Nee Ting & 1570637631 \\
\hline Ron Aldrino Chan & 1570637780 \\
\hline Mohammad Ibrahim Safawi bin Mohammad Zain & 1570646436 \\
\hline
\end{tabular}

